\title{
HISTORY OF ART
}

\section{CHURCH LAMP COLLECTION IN THE COLLECTION OF THE NATIONAL HISTORICAL-ETHNOGRAPHIC RESERVE «PEREIASLAV»}

\section{Svitlana Avramenko ${ }^{1}$}

DOI: https://doi.org/10.30525/978-9934-588-11-2_23

At the beginning of the Christian religion, a lamp was filled with oil. It was used to illuminate the caves in which believers secretly prayed, fearing persecution. Then church lamps began lighting in temples during evening worship and in daylight.

The introduction of Christianity in the Old Russian state contributed to the development of cult building. In the temples the lamps lighted before the shrines: the Gospel, the icons of the saints. Gradually, they became an integral part of the traditional Orthodoxy rituals: christening, wedding, burial.

Gradually the peasants faith pagan faith changed the household protected of the heathen religion into the icons. The lamps were lighted in front of icons. At the end of the 19th-at the beginning of the $20^{\text {th }}$ century in each Orthodox house there was a peculiar home altar with icons on the special shelves. In front of the icons were placed one or more church lamps. They were shone during prayer, as well as during fasting and major church holidays. Sometimes the unbearable church lamp was lighted in the house and it had been burning for a whole day. It was considered that fire cleaned the house from evil and symbolize the continuity of prayer to God.

Numerical demand for lamps was satisfied by craftsmen and small specialized workshops, that located on the lands of monasteries: Kyiv-Pechersk Lavra, Pochayiv Lavra, Mezhigir Monastery and others [2, p. 80].

Since the 20 's $19^{\text {th }}$ century, as a result of the state's devastating policies, the authorities in Ukraine have intensified the practice of confiscating religious buildings from religious communities. A lot of the sacred objects were removed from the churches and transferred to public authorities, in private hands, to museum collections for the purpose of conducting anti-religious state policy. Just these circumstances of conservation have protected them from destruction and today they give possibility for Ukrainian society joining to Christian values [1, p. 46].

«Pereiaslav» National Historical and Ethnographic Reserve has a large number of museum objects of sacred importance.

Many of such artifacts are displayed at the Museum of Folk Architecture and Everyday life in the Middle Naddniprianshchyna. The reserve «Pereiaslav» represents the Ukrainian village at the end of the19th century- the beginning of the

${ }^{1}$ Pereiaslav National Historical and Ethnographic Reserve, Ukraine 
20th century. In the second half of the twentieth century, a significant number of church supplies were collected by museum staff to recreate the interiors of rural churches and people's homes. At the same time, a collection of church lamps was assembled the end of the $19^{\text {th }}$ century-the beginning of the $20^{\text {th }}$ century. It is numerically small (58 items), but it's valuable in its historical and artistic significance. The objects in the museum collection were come from ethnographic expeditions that worked on the territory of the Middle Naddniprianshchyna [2, p. 79].

The collection was formed for three periods. The first lamps came to the stock collection in the early the 60 's of the 20 century, (to create the interiors of the dwellings and churches of the Museum of Folk Architecture and Everyday life in the Middle Naddniprianshchyna).

The second period - the 70-80s of the 20 century. At that time, the Kaniv Hydroelectric Power Plant was being constructed on the Dnieper River, an artificial reservoir was being created, and dozens of settlements were evicted from the flood zone. From this area, lamps for the museum collection were selected from the dwellings and temples.

The next period of formation of the collection is 1990-2000, when church objects were received to the museum collection, both from expeditions and donated by individuals, passed to the customs authorities and other institutions.

The hanging church lamps are the most fully represented in the collection of the National Historical and Ethnographic Reserve «Pereiaslav». They are on three chains, considered the most practical, because they can be attached to the icon at any level. The chains were fastened to the ears of the product or frame, at the top were assembled into a «beam» or joined to a miniature «disk» with a ring [3].

The most numerous group of hanging lamps consist of objects made of glass of different shape, manufacturing technique, method of decoration. Both colorless and colored glass (red, blue, green) were used to make them. The red lights are lit for Easter, the greens are lit for the year. Blue and colorless are used at Great fast.

The collection is presented with hanging church lamps in a metal frame. They consist of several parts: a metal frame, a glass cup for oil, chains holding a hanging church lamp, and a cap that catches the soot. The metal frame is decorated with a variety of patterns.

There are two hanging church lamps as the shape of a dove, the third - has the shape of a church top. They are manually painted with paints and gilding [3].

An interesting museum item is a lamp with a bracket, which has a side attachment to the icon, or the goddess. It has a metal frame rigidly attached to the L-shaped leg, into which a glass glass is inserted [3].

The church lamp is designed for the house. It contains 100-150 grams of lamp oil and it can burn two or three days. It is customary to light it from a church candle.

The museum collection is presented several lamps that were used only in temples.

The collection of lamps of «Pereiaslav» National Historical and Ethnographic Reserve arouses a great interest to excursionists and scientists and it needs further art studies. 


\section{References:}

1. Bouquet, E. (2015). Muzeini predmety iz fondovoi kolektsii NIEZ «Pereiaslav», shcho pokhodiat $\mathrm{z}$ sela Hruzkoho Makarivskoho raionu Kyivskoi oblasti [Museum items from the Pereyaslav National Research Institute stock collection, originating from the village of the Georgian Makariv district of Kyiv region]. Pereiaslavik: Scientific notes of the National Historical and Ethnographic Reserve «Pereyaslav»: Collection of scientific articles, vol. 9 (11), p. 46.

2. Godlina, L., \& Dunayna, I. (2014). Kultovi atrybuty u zbirtsi Natsionalnoho istorykoetnohrafichnoho zapovidnyka «Pereiaslav» [Cult attributes in the collection of «Pereyaslav» National Historical and Ethnographic Reserve]. Pereiaslavik: Scientific Notes of «Pereiaslav» National Historical and Ethnographic Reserve: Coll. Sciences. Articles, vol. 7 (9), pp. 79-80.

3. Materialy fondovoi inventarnoi knyhy Natsionalnoho istoryko-etnohrafichnoho zapovidnyka «Pereiaslav». Inventarna hrupa «K» (Keramika»), «NDF» («Naukovo-dopomizhnyi fond»), «PKhIM» («Pereiaslav-Khmelnytskyi istorychnyi muzei»). [Materials of the stock inventory book of «Pereiaslav» National Historical and Ethnographic Reserve. Inventory group «C» (Ceramics), «SSF» (Scientific Support Fund), «PKHM» (Pereyaslav-Khmelnitsky History Museum)].

\section{WOMEN'S EARRING COLLECTION IN NATIONAL HISTORICAL-ETHNOGRAPHIC RESERVE «PEREIASLAV»}

\section{Iryna Dunaina ${ }^{1}$}

DOI: https://doi.org/10.30525/978-9934-588-11-2_24

The Ukrainian women's folk ornaments collection in the National Historical and Ethnographic Reserve (hereinafter referred to as NIEZ «Pereiaslav») began to form in 1959.It represents the neck, chest, ear jewelry which refer to the lands of the Middle Dnieper region, in particular Pereyaslav, Poltava, Kyiv, Left and Right (partly) Cherkasy and Chernihiv (partly) regions. The collection contains about 311 pieces of museum artifacts of late XVIII - mid. XX century, which are recorded and stored in the stock groups of «Numismatic», «Fabric».

These are :

- necklace - 147 pieces;

- chain - 7 pieces;

- dukach (lychman), bow - 102 pieces;

- medallion - 1 piece;

- Earring - 50 pieces;

- brooch -4 pieces.

Thanks to museums, which meticulously were engaged in scientific and practical work on the identification, attribution, preservation and introduction to the scientific circulation of the historical and cultural heritage of the people, these artifacts of folk culture have taken a prominent place in museum collections. The museum collection was created thanks to the ethnographic expeditions of the reserve, which worked in

\footnotetext{
${ }^{1}$ National Historical and Ethnography Reserve «Pereiaslav», Ukraine 